\title{
Physiological Studies on Cancer irroratus Larvae. III. Effects of Temperature and Salinity on the Partitioning of Energy Resources During Development*
}

\author{
D. Michael Johns \\ United States Environmental Protection Agency, Environmental Research Laboratory, South Ferry Road, Narragansett, \\ Rhode Island 02882, USA \\ and \\ Belle W. Baruch Institute for Marine Biology and Coastal Research, University of South Carolina, Columbia, \\ South Carolina 29208, USA
}

\begin{abstract}
Balanced energy budgets were estimated for larval stages of the rock crab Cancer irroratus cultured in 6 combinations of temperature and salinity. The energy consumed by larvae during development increased in all culture conditions although consumption in $10^{\circ} \mathrm{C}-30 \% \mathrm{~S}$ was significantly lower than for larvae in other conditions $\left(15^{\circ} \mathrm{C}-25 \% \mathrm{~S}, 15^{\circ} \mathrm{C}-30 \% \mathrm{~S}, 15^{\circ} \mathrm{C}-35 \%, 24^{\circ} \mathrm{C}\right.$ $-30 \%$ S). Maintenance costs for the entire developmental period were highest for larvae cultured at $10{ }^{\circ} \mathrm{C}-30 \% \mathrm{~S}$ and $15{ }^{\circ} \mathrm{C}-25 \% \mathrm{~S}$. Larvae under these conditions had net growth efficiencies of only $32-34 \%$. In the other temperature and salinity conditions tested, the amount of energy expended for maintenance was generally equal to the amount of energy converted to new tissue with net growth efficiencies varying between 48 and $51 \%$. These data suggest that the larva's ability to acquire energy resources and effectively partition the energy obtained between maintenance and growth depends on environmental factors. Under certain conditions $\left(10^{\circ} \mathrm{C}-30 \% \mathrm{~S}, 15^{\circ} \mathrm{C}-25 \% \mathrm{~S}\right)$ larvae are unable to compensate physiologically for environmental changes. One consequence of incomplete physiological compensation is a reduced potential for growth and an overall reduction in the organism's ecological fitness within the zooplankton community.
\end{abstract}

\section{INTRODUCTION}

Laboratory studies on Cancer irroratus larvae show close correlation between the physiological ecology of the larvae (Johns, 1980) and their occurrence in southern New England waters (Frolander, 1955; Hillman, 1964). The larvae are eurythermal and stenohaline during development, surviving temperatures between $10^{\circ}$ and $23^{\circ} \mathrm{C}$ in salinities of 30 to $35 \% \mathrm{~S}$ (Johns, 1981a). Within these tolerance limits, temperature and salinity play a significant role in the growth dynamics of the larvae. Molt frequency, intermolt duration, larval size (Sastry, 1976; Johns, 1981a) as well as respira-

- Contribution No. 260 from EPA Environmental Research Laboratory, Narragansett, Rhode Island and Contribution No. 431 from the Belle W. Baruch Institute for Marine Biology and Coastal Research, Columbia, South Carolina, USA tion and excretion rate functions are all influenced by temperature and salinity (Johns, 1981b).

In order to understand better the interaction of developing Cancer irroratus larvae with their environment, it is necessary to integrate the response of individual biological functions. Although the fundamental integration of biochemical and physiological mechanisms is complex and difficult to measure (Hochachka and Somero, 1973) the net response can be measured at the whole-organism level (Bayne, 1975). Bioenergetic analysis compares the major anabolic and catabolic processes occurring during development. The partitioning of available energy resources amongst growth and maintenance requirements provides an index by which environmental effects can be directly evaluated.

In this study, balanced energy budgets were constructed for larvae of the rock crab Cancer irroratus cultured in 6 combinations of temperature and salinity. 
Much of the data used to compute these energy budgets were derived from a series of companion studies (Johns, 1981a, b) which were part of an investigation into the physiological ecology of $C$. irroratus larvae.

\section{MATERIALS AND METHODS}

Gravid Cancer irroratus were collected by otter trawl from the West Passage of Narragansett Bay, Rhode Island, from December to May of 1977 through 1979 Methods for laboratory maintenance of the gravid adults, procurement of newly-hatched zoeae and the mass culture techniques used in this study are presented in detail elsewhere (Johns, 1981a). Larvae were cultured under the following temperature-salinity conditions: $10^{\circ} \mathrm{C}-30 \% \mathrm{~S}, 15^{\circ} \mathrm{C}-25 \% \mathrm{~S}, 15^{\circ} \mathrm{C}-30 \% \mathrm{~S}$, $15^{\circ} \mathrm{C}-35 \% \mathrm{~S}, 24^{\circ} \mathrm{C}-25 \% \mathrm{~S}, 24^{\circ} \mathrm{C}-30 \% \mathrm{~S}$.

The energy budget of a crab larva can be defined by the following formula:

$$
C=P+R+U_{E}+U_{E X U V}+F
$$

where $C=$ total intake of energy; $P=$ the portion of energy incorporated into biomass; $R=$ the portion of energy used for metabolic expenditure via respiration; $U_{E}+U_{E X U V}=$ portions of energy which are absorbed but eventually lost both through excretion of metabolic wastes $(E)$ and as exoskeleton shed during molting $(E X U V) ; F=$ the portion of energy consumed that is not absorbed but instead voided as feces.

Values for $C, P, R, U_{E}+U_{E X U V}$ were arrived at experimentally; $F$ was calculated through subtraction. Energy lost as feces could not be directly determined due to problems in collecting sufficient samples for analysis. Ingestion rates, respiration rates, excretion rates, larval dry weights and ash contents were determined for groups of larvae at each zoeal stage. For Stage I zoea, these determinations were made between 24 and 36 h after hatching. For all successive stages, the larvae were between 24 and $36 \mathrm{~h}$ post-molt from the previous larval stage. Mean molting times for each larval stage were determined from a sample of larvae maintained in screen-bottomed plastic cups within the flow-through system (Johns, 1981a). All larvae were fed newly-hatched Brazil-strain Artemia (Johns et al., 1980). At this stage, brine shrimp nauplif weigh $1.68 \pm 0.11 \mu \mathrm{g}$; they have an ash content of approximately $5.4 \%$ and an energy content of $22.35 \pm 0.04$ Joules $\mathrm{g}^{-1}$ ash-free dry weight $(5.322 \mathrm{Kcal} \mathrm{g}$ ash-free dry $\mathrm{wt}^{-1}$ ), as determined by wet oxidation in the presence of an acid-dichromate mixture (Maciolek, 1962).

Ingestion was measured by placing an individual crab larvae in a $5 \mathrm{ml}$ beaker containing $4 \mathrm{ml}$ of filtered seawater having 10 Artemia $\mathrm{ml}^{-1}$. Ingestion rates were figured as the difference between the number of Artemia initially present and those remaining after a $24 \mathrm{~h}$ period.

The total energy consumed per larva during zoeal stages was calculated as the energy consumed per larva per day times the mean duration of larval development. The energy consumption estimates assume that the feeding rate of a larva within a particular stage remains constant during that intermolt period and that each Artemia absent after 24 h was fully eaten by the zoea. Dagg (1974) reported that predatory crustaceans do not always consume the entire body contents of their prey. However, in this study no partially eaten Artemia were observed during these determinations.

Growth during a particular zoeal stage was defined as the mean increase in dry weight from the beginning of that zoeal stage to the beginning of the following stage. Individuals were sampled from each respiratory run as well as from the mass-culture chambers. The larvae were then rinsed in $0.9 \%$ ammonium formate (W:V), dried in a $60^{\circ} \mathrm{C}$ oven for $24 \mathrm{~h}$ and weighed on a Perkin-Elmer ${ }^{*}$ autobalance to the nearest $0.1 \mu \mathrm{g}$. The ash weights were calculated by combusting weighed dried larvae at $500^{\circ} \mathrm{C}$ for $24 \mathrm{~h}$, then reweighing.

Routine rates of oxygen consumption were measured with glass micro-respirometers (Grunbaum et al., 1955). The number of larvae used in each determination varied according to larval size, with more individuals being required for the younger stages. The protocol followed is described in detail in Johns (1981b). The energy expended during routine metabolism at each zoeal stage was considered to be the respiration rate for the intermolt period of that stage times the energy equivalent for oxygen $\left(2.02 \times 10^{-2}\right.$ Joule $\mu 1^{-1} \mathrm{O}_{2}$ consumed; Brody, 1945).

Excretion rates were found for groups of larvae placed in $10 \mathrm{ml}$ of $0.45 \mu \mathrm{m}$ filtered seawater for up to $5 \mathrm{~h}$; ammonia concentrations were determined according to the method of Solorzano (1969). The protocol followed is reported in Johns (1981b). Calories lost through excretion were calculated as the mean excretion rate per intermolt period times the heat of formation of ammonia $\left(7.37 \times 10^{-3}\right.$ Joule $\mu g^{-1} \mathrm{NH}_{4}-\mathrm{N}$; Logan and Epifanio, 1978).

To determine the amount of energy lost at ecdysis, the energy content of samples of exuviae was measured following a rinse in distilled water. Molts were only collected for larvae cultured at $15^{\circ} \mathrm{C}-30 \% \mathrm{~S}$.

A one-way analysis of variance was computed to determine the effects of rearing condition on larval ingestion rates (Snedecor and Cochran, 1967). If sig-

\footnotetext{
- Mention of tradenames does not imply endorsement by the
} United States Environmental Protection Agency 
nificant differences (at $\mathrm{P}=0.05$ ) in crab feeding levels at different temperature-salinity conditions were found, a Duncan's Multiple Range test was applied to determine where the differences occurred (Snedecor and Cochran, 1967). Data on the effects of temperature and salinity on larval growth were logarithmically transformed and fitted to a least-squares linear regression model. The resulting fitted lines were subsequently tested for significant differences using equality of regression analyses (Snedecor and Cochran, 1967).

The energy budgets presented in this study were calculated using the arithmetic mean of each individual physiological parameter. The error associated with the variation found about the mean was not taken into account. If the errors associated with the variance of each measurement were of the worst possible case (i.e. underestimation of energy consumed and energy converted to tissue, in addition to an overestimation of maintenance costs and excretory losses), then the resulting energy balance would be quite different from that calculated from one using mean values. However, Bayne and Widdows (1978) consider such a worst possible case of cumulative error to be unlikely. Instead they argue, using a Monte Carlo simulation, that error associated with calculating an energy balance using arithmetic means is small and that such energy balances offer reasonable, first-order approximations. It is therefore appropriate to consider the energy budgets developed here for rock crab larvae to be useful estimates for larvae under the conditions of this study.

\section{RESULTS}

\section{Ingestion Rate}

Ingestion rates of Artemia by Cancer irroratus larvae increased throughout larval development for larvae reared at all temperature and salinity conditions tested (Table 1). The amount of food consumed during development was maximal for larvae maintained at $15^{\circ} \mathrm{C}-35 \% \mathrm{~S}$. However, the amount of Artemia consumed was not significantly different from consumption rates of larvae cultured at either $15^{\circ} \mathrm{C}-25 \% \mathrm{~S}$, $15^{\circ} \mathrm{C}-30 \% \mathrm{~S}$, or $24^{\circ} \mathrm{C}-30 \% \mathrm{~S}$ (Table 2 ).

The amount of energy consumed per larva per stage, as well as the total amount of energy consumed per larva for the entire larval period, is presented in Table 1. Larvae cultured at $15^{\circ} \mathrm{C}$ consumed more energy than did larvae maintained at other temperatures. Within the $15^{\circ} \mathrm{C}$ group, the larvae were affected by salinity with larvae in the lower salinities exhibiting decreased rates of energy consumption. Larvae cultured at $10^{\circ} \mathrm{C}-30 \% \mathrm{~S}$ had significantly lower daily feeding rates than did larvae reared at $24^{\circ} \mathrm{C}-30 \% \mathrm{~S}$, but because development time at $10^{\circ} \mathrm{C}$ was longer $(50$ d vs. 19 d), the larvae at these two contrasting temperature conditions had similar cumulative energy consumption totals for the entire larval period.

\section{Growth}

The increase in dry weight during development is tabulated in Table 3 . The greatest increases in larval weight were found for larvae cultured at $15^{\circ} \mathrm{C}-$ $30 \%$ S, with these larvae increasing their weight 24 times from hatching to the beginning of the megalopa stage. The lowest weight increase for the same developmental sequence was found in larvae cultured at $10^{\circ} \mathrm{C}-30 \% \mathrm{~S}$, which exhibits only a 13 fold increase in dry weight. Increases in weight for larvae cultured at $15^{\circ} \mathrm{C}-35 \% \mathrm{~S}$ and $24^{\circ} \mathrm{C}-30 \% \mathrm{~S}$ were similar to

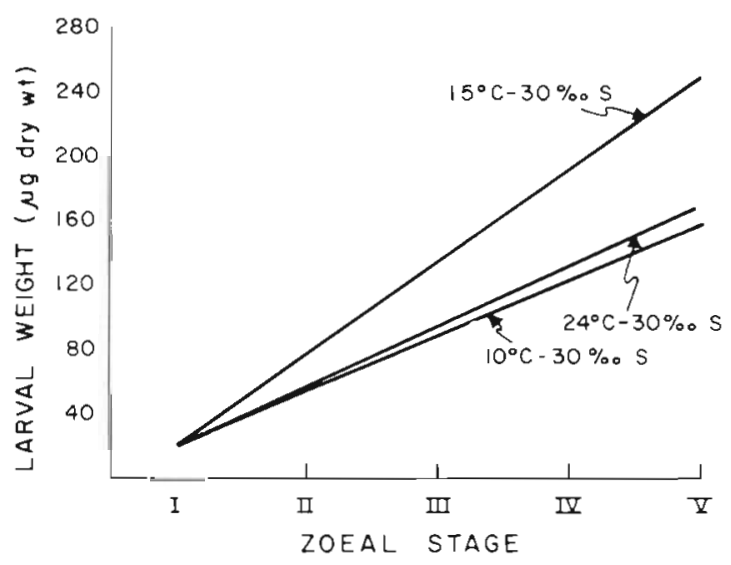

Fig. 1. Cancer irroratus. Growth of zoeae cultured at various temperatures in $30 \% \mathrm{~S}$. Lines represent raw data fitted by regression analysis

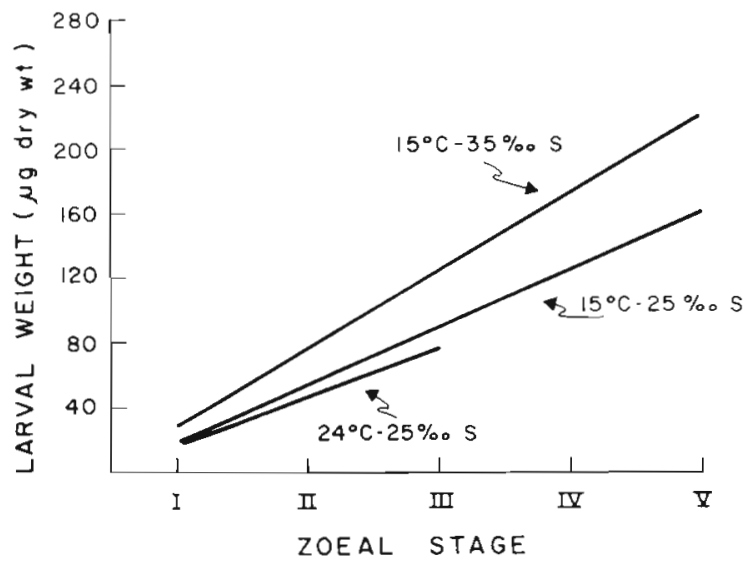

Fig. 2. Cancer irroratus. Growth of zoeae cultured in various temperature-salinity combinations. Lines represent raw data fitted by linear regression analysis 


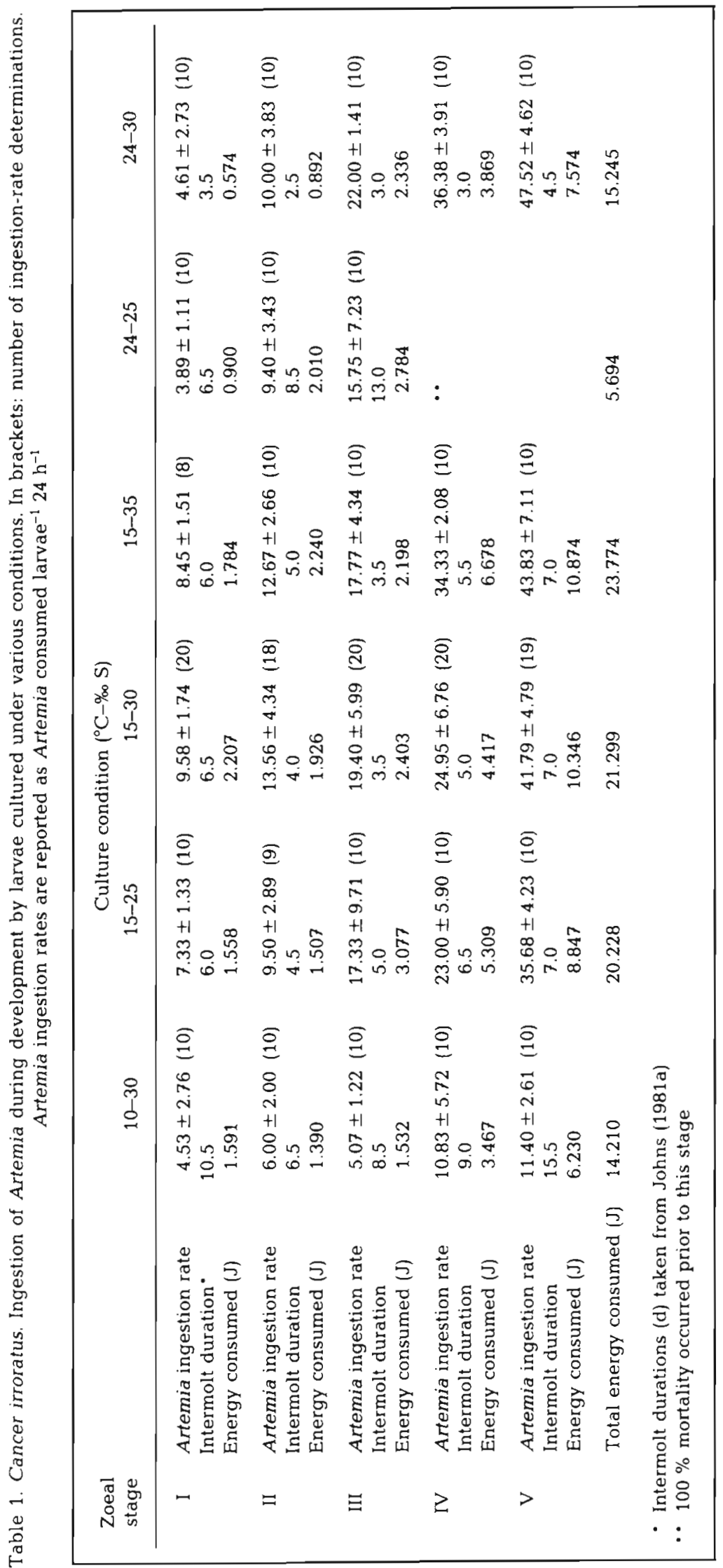




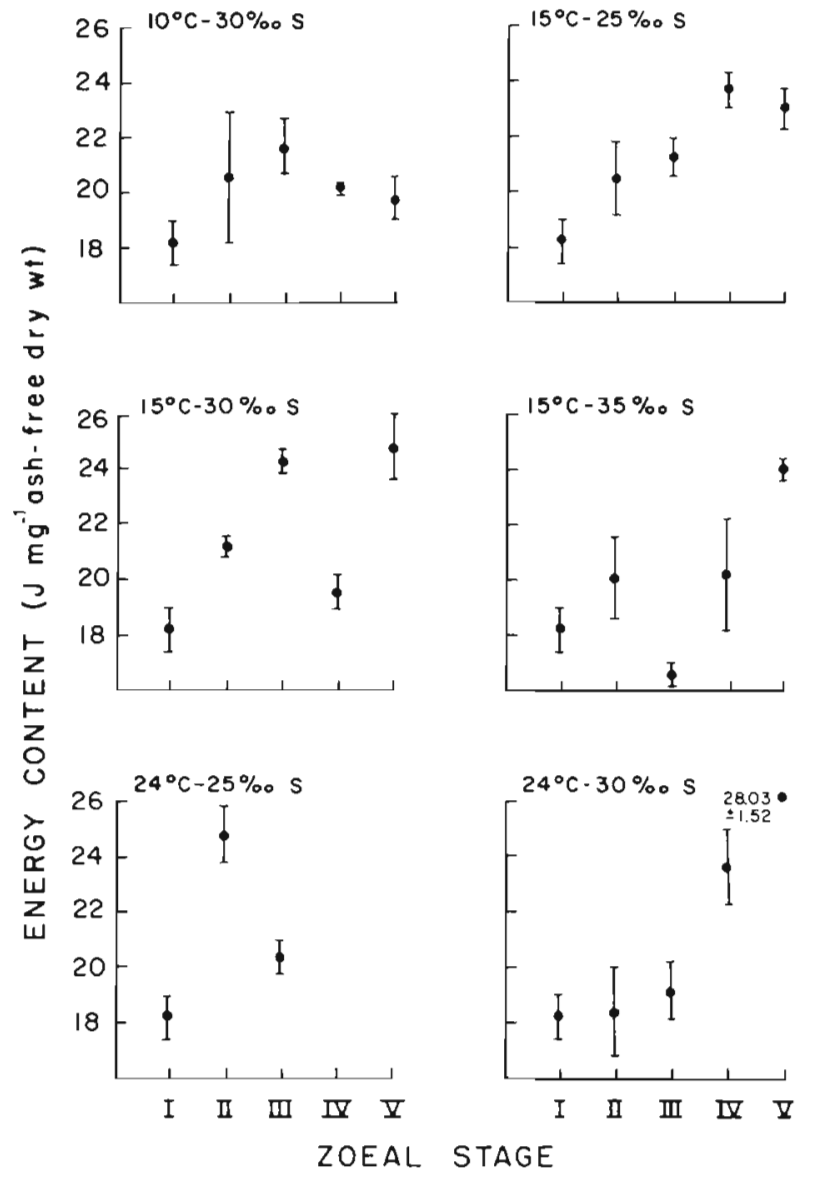

Fig. 3. Cancer irroratus. Energy content of zoeal stages cultured in various combinations of temperature and salinity. Values represent mean \pm 1 standard deviation of at least 3 determinations those found in larvae maintained at $15^{\circ} \mathrm{C}-30 \% \mathrm{~S}$, the increases being 22 and 23 fold, respectively.

Linear regression analysis of logarithm transformed growth data indicates that both temperature and salinity affect larval growth rates (Figs. 1, 2; Table 4). The rate of growth in larvae cultured at $15^{\circ} \mathrm{C}-30 \% \mathrm{~S}$ was significantly greater $(\mathrm{P} \geq 0.05)$ than were the growth rates of larvae cultured at all other conditions. Growth rates for larvae maintained at conditions other than $15^{\circ} \mathrm{C}-30 \% \mathrm{~S}$ were not significantly different from each other $(\mathrm{P}>0.05)$.

Changes in the energy content of larval tissue during growth are depicted in Fig. 3. Energy content of an ash-free $\mathrm{mg}$ of tissue increased from $18.23 \mathrm{~J} \mathrm{~g}^{-1}$ at hatching to a maximum of $28.03 \mathrm{~J} \mathrm{~g}^{-1}$ at Stage $\mathrm{V}$ at $24{ }^{\circ} \mathrm{C}-30 \% \mathrm{~S}$. During development, there was a general tendency for the energy content of tissue to increase, with this trend being most apparent in larvae cultured at $24{ }^{\circ} \mathrm{C}-30 \% \mathrm{~S}$. There were several exceptions to this trend, however. Most notable is the change at $10^{\circ} \mathrm{C}-30 \% \mathrm{~S}$ and $24^{\circ} \mathrm{C}-25 \% \mathrm{~S}$. The initial pattern of increase in the energy content of the larval tissue was followed by a decrease as development progressed to zoeal Stages IV and V.

\section{Metabolic Costs}

Routine respiration rates were found to increase with increasing body size, reflecting a rise in the metabolic cost of maintenance during development (Table 5). Cumulative respiration rates were higher in larvae

Table 2. Cancer irroratus. Analysis of variance of ingestion rates for zoeal stages cultured in various conditions of temperature and salinity. Ingestion rates from culture conditions grouped on the same line are not significantly different from each other

\begin{tabular}{|c|c|c|c|c|c|c|}
\hline Zoeal stage & & S.S. & d.f. & M.S. & F-Ratio & Grouping \\
\hline I & $\begin{array}{l}\text { Treatment } \\
\text { Error } \\
\text { Total }\end{array}$ & $\begin{array}{l}248.82 \\
211.06 \\
459.88\end{array}$ & $\begin{array}{r}5 \\
52 \\
57\end{array}$ & $\begin{array}{r}49.76 \\
4.06 \\
-\end{array}$ & $\begin{array}{c}- \\
12.26\end{array}$ & $\begin{array}{l}10-30 ; 24-25 ; 24-30 \\
15-25 ; 15-30 ; 15-35\end{array}$ \\
\hline II & $\begin{array}{l}\text { Treatment } \\
\text { Error } \\
\text { Total }\end{array}$ & $\begin{array}{l}292.15 \\
505.85 \\
789.00\end{array}$ & $\begin{array}{r}5 \\
42 \\
47\end{array}$ & $\begin{array}{c}58.43 \\
12.04 \\
-\end{array}$ & $\begin{array}{c}- \\
- \\
4.85^{\circ}\end{array}$ & $\begin{array}{c}10-30 ; 15-25 ; 24-25 ; 24-30 \\
15-30 ; 15-35\end{array}$ \\
\hline III & $\begin{array}{l}\text { Treatment } \\
\text { Error } \\
\text { Total }\end{array}$ & $\begin{array}{l}1321.83 \\
1085.32 \\
2407.16\end{array}$ & $\begin{array}{r}5 \\
38 \\
43\end{array}$ & $\begin{array}{c}264.37 \\
28.56 \\
-\end{array}$ & $\begin{array}{c}- \\
\overline{9} . \\
9 .\end{array}$ & $\begin{array}{c}10-30 \\
15-25 ; 15-30 ; 15-35 ; 24-25 ; 24-30\end{array}$ \\
\hline IV & $\begin{array}{l}\text { Treatment } \\
\text { Error } \\
\text { Total }\end{array}$ & $\begin{array}{l}1415.68 \\
1163.61 \\
2579.30\end{array}$ & $\begin{array}{r}4 \\
32 \\
36\end{array}$ & $\begin{array}{c}353.92 \\
36.36 \\
-\end{array}$ & $\begin{array}{c}- \\
- \\
9.73^{*}\end{array}$ & $\begin{array}{c}10-30 \\
15-25 ; 15-30 ; 15-35 ; 24-30\end{array}$ \\
\hline V & $\begin{array}{l}\text { Treatment } \\
\text { Error } \\
\text { Total }\end{array}$ & $\begin{array}{r}1903.16 \\
722.25 \\
2625.41\end{array}$ & $\begin{array}{r}3 \\
23 \\
26\end{array}$ & $\begin{array}{c}634.39 \\
31.40 \\
-\end{array}$ & $\begin{array}{c}- \\
- \\
20.20^{\circ}\end{array}$ & $\begin{array}{c}10-30 \\
15-25 ; 15-30 ; 15-35 ; 24-30\end{array}$ \\
\hline
\end{tabular}




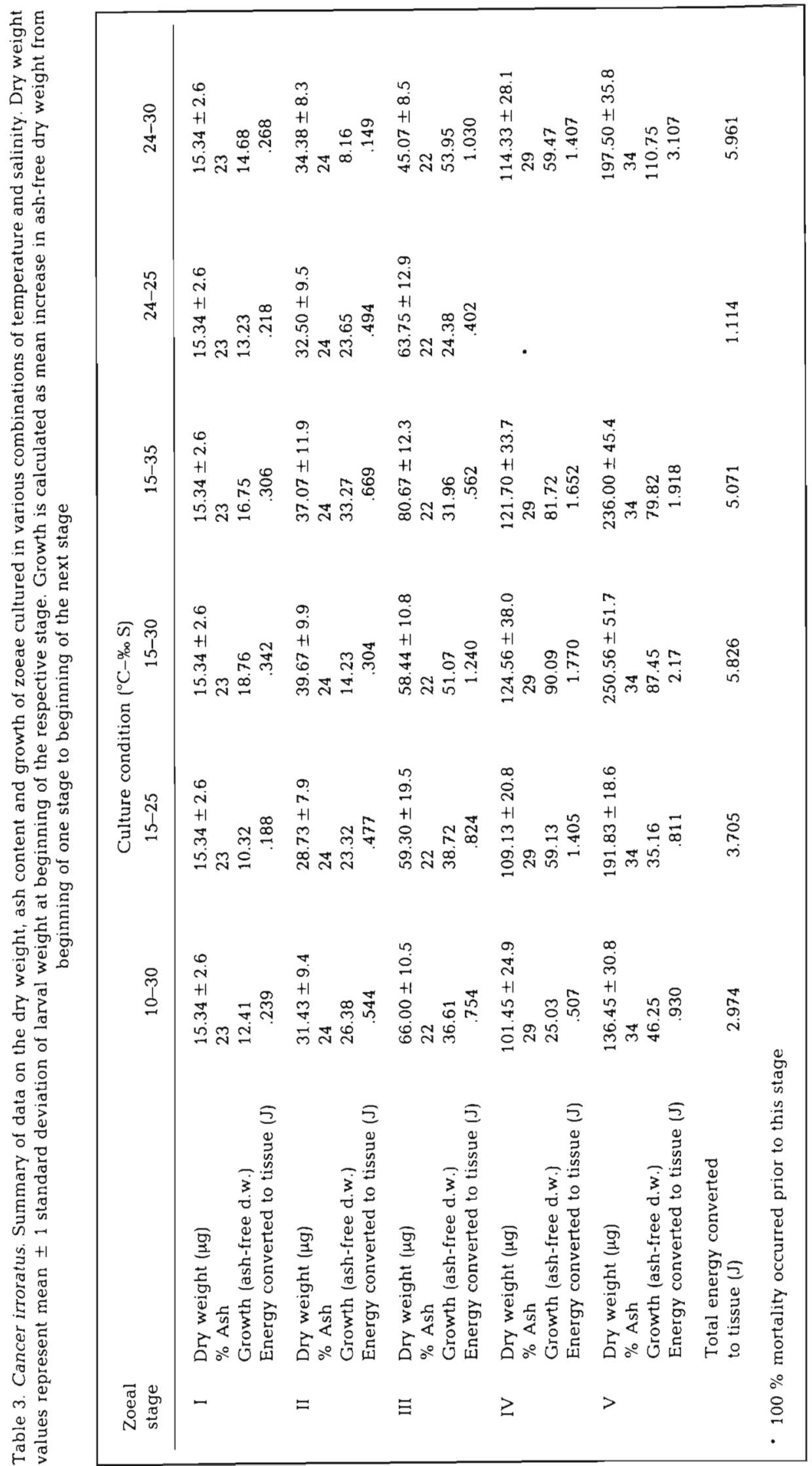


Table 4. Cancer irroratus. Fitted regression lines used to analyze growth rates for zoeal stages cultured in various conditions of temperature and salinity. n: number of dry weight determinations; b: regression coefficient for the fitted regression line; r: correlation coefficient

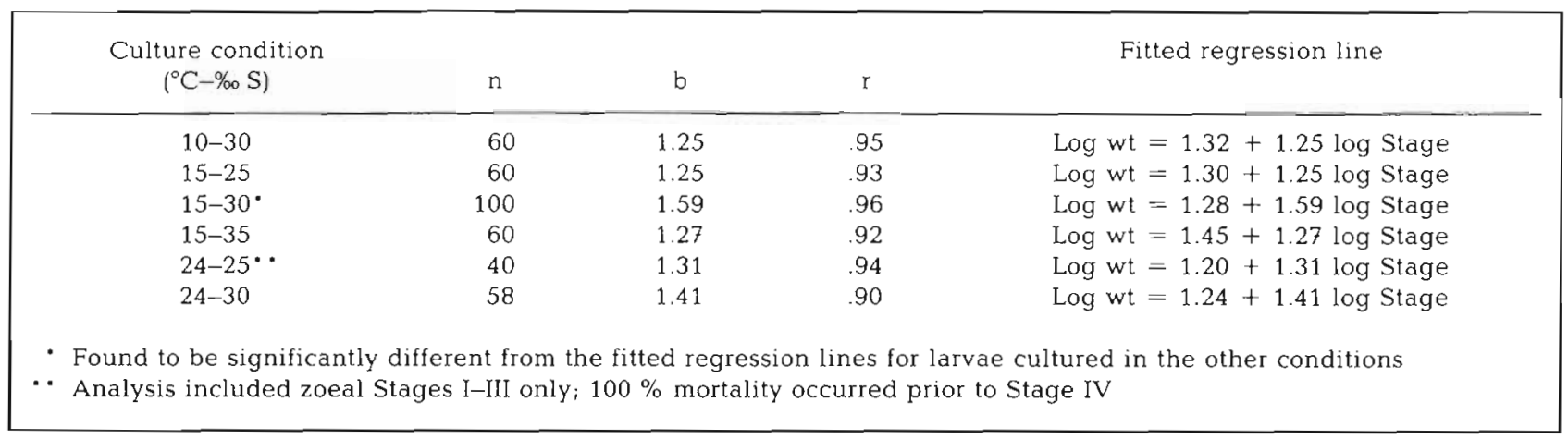

cultured at $10^{\circ} \mathrm{C}-30 \% \mathrm{~S}$ and $15^{\circ} \mathrm{C}-25 \% \mathrm{~S}$ than in larvae maintained at the other conditions. The higher cumulative rates found in larvae cultured at $10^{\circ} \mathrm{C}-$ $30 \%$ S can be attributed to a protracted development period rather than due to inordinately high metabolic demands, while the cumulative rates for larvae cultured at $15^{\circ} \mathrm{C}-25 \% \mathrm{~S}$ were due to the relatively high respiration rates of each zoeal stage.

As with respiration, excretion rates were also found to increase as development progressed (Table 6). The amount of energy lost as metabolic wastes during zoeal development ranged from $0.120 \mathrm{~J}_{\text {larva }}{ }^{-1}$ to $0.270 \mathrm{~J}$ larva $^{-1}$, with the highest total losses found in larvae cultured at both $10^{\circ} \mathrm{C}-30 \%$ S and $15^{\circ} \mathrm{C}-25 \%$ S

\section{Molting Costs}

The energy lost at molting due to the loss of the exuviate increased as the size of the exoskeleton increased. The amount of energy lost for the entire larval period was $0.177 \mathrm{~J} \mathrm{larva}^{-1}$ representing a loss of $0.005 \pm .002,0.008 \pm .002,0.013 \pm .008,0.036 \pm .007$ and $0.115 \pm .009 \mathrm{~J} \mathrm{larva}^{-1}$ for zoeal Stages I through $\mathrm{V}$, respectively.

\section{Partitioning of Energy Resources}

The above data have been used to calculate cumulative energy budgets for the entire zoeal period and the associated energetic efficiencies (Table 7). Space does not permit tabulation of the energy budgets for each zoeal stage. However, budgets for each stage can be calculated from the data presented in previous tables using a method similar to that used for the cumulative budgets.

Energy consumed (Column $C$ ) is partitioned into the various life processes (Columns $P, R, U_{E}, U_{E X U V}$ ) or lost as feces (Column $F$ ). The two physiological processes demanding the largest energy expenditure are growth and metabolic maintenance. For larvae reared at $15^{\circ} \mathrm{C}$ - $30 \% \mathrm{~S}$ and $24{ }^{\circ} \mathrm{C}-30 \% \mathrm{~S}$, more energy was converted into new tissue than was used for metabolic maintenance, while the opposite held true for larvae cultured at the other conditions tested.

The efficiency at which ingested food is made available for physiological purposes, commonly referred to as the assimilation efficiency $\left(A=P+R+U_{E}+\right.$ $U_{\text {EXUV }} / C \times 100 \%$ ), ranged from 45 to $77 \%$ (Table 8 ). This wide range in efficiencies indicates that temperature and salinity can greatly modify the ability of rock crab larvae to assimilate food during digestion.

Gross growth $(P / C \times 100 \%)$ and net growth $(P / A \times$ $100 \%$ ) efficiencies were estimated and found to be dependent upon larval rearing conditions (Table 8). For net growth efficiency, 3 levels of efficiency were found. The highest, ranging from 48 to $51 \%$, was found for larvae cultured at $15^{\circ} \mathrm{C}-30 \% \mathrm{~S}, 15^{\circ} \mathrm{C}-35 \% \mathrm{~S}$ and $24{ }^{\circ} \mathrm{C}-30 \% \mathrm{~S}$. An intermediate level of 32 to $34 \%$ was found for larvae cultured at $10^{\circ} \mathrm{C}-30 \% \mathrm{~S}$ and $15^{\circ} \mathrm{C}-$ $25 \% \mathrm{~S}$, and the lowest efficiency $(20 \%)$ was found for larvae maintained at $24{ }^{\circ} \mathrm{C}-25 \% \mathrm{~S}$ (data for the first 3 zoeal stages only).

\section{DISCUSSION}

Many marine organisms have a pelagic stage in their life histories. Larval development is generally rapid in which growth and morphogenesis are at a premium. Successful development is dependent upon the efficient assimilation of energy (either yolk material or ingested food) and its subsequent conversion to tissue. A critical factor in development, however, is in maintaining a high rate of growth in the face of environmental change. Although some growth did occur in Cancer irroratus larvae maintained under the environ- 

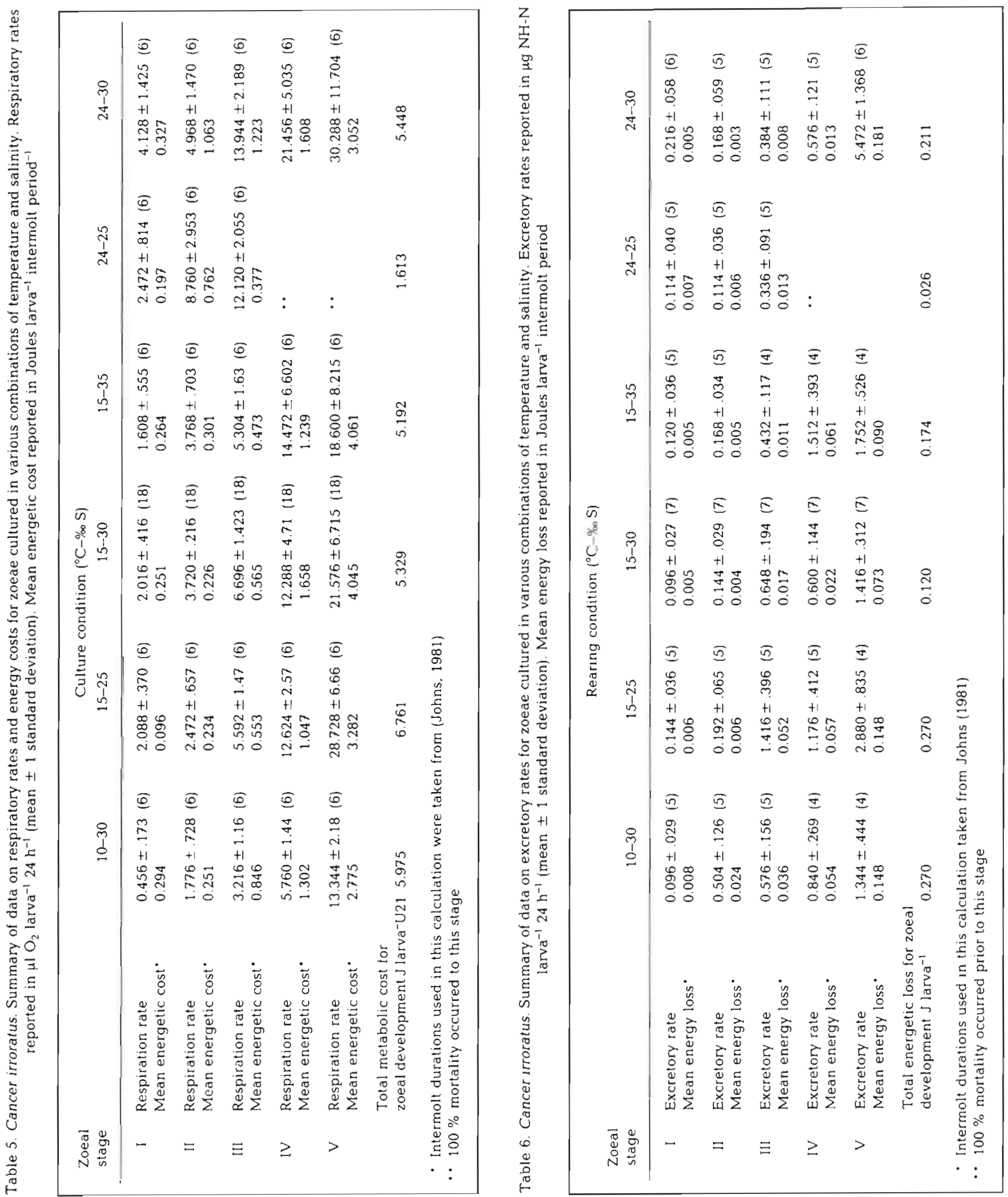
Table 7. Cancer irroratus. Mass energy balance for zoeal Stages I-IV cultured in various conditions of temperature and salinity All values reported in Joules

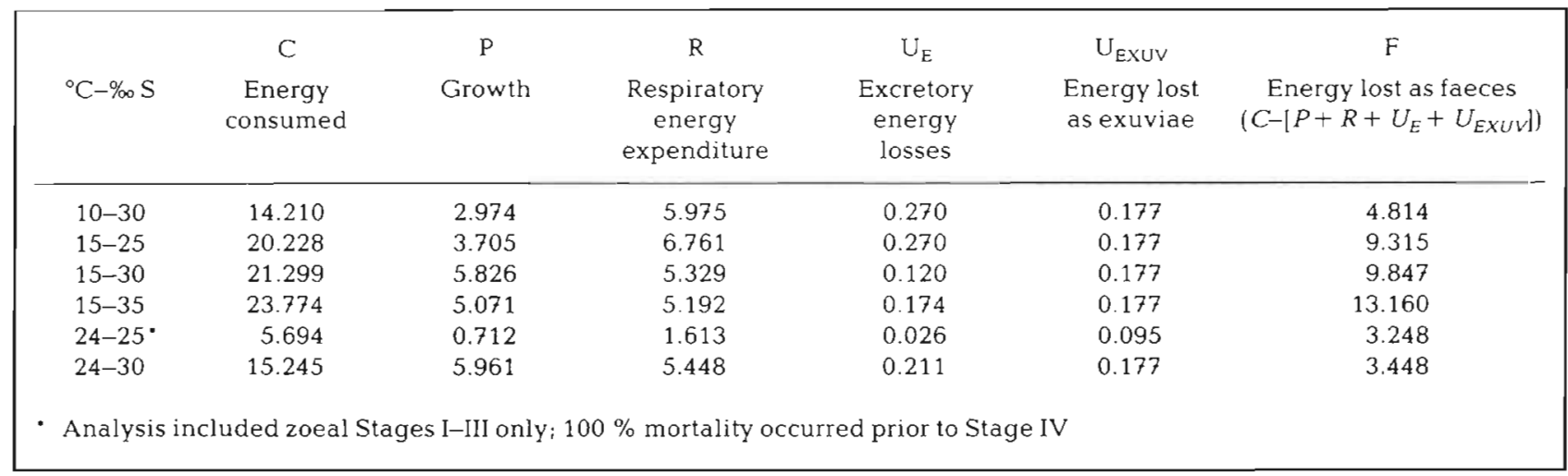

Table 8. Cancer irroratus. Energetic efficiencies during zoeal development for zoeal Stages I-V cultured in various conditions of temperature and salinity

\begin{tabular}{|cccc|}
\hline $\begin{array}{c}\text { Culture } \\
\text { Condition } \\
\left({ }^{\circ} \mathrm{C}-\% \mathrm{~S}\right)\end{array}$ & $\begin{array}{c}\text { Assimilation } \\
\text { efficiency } \\
(P+R+ \\
\left.U_{E}+U_{\text {Exud }} / C\right)\end{array}$ & $\begin{array}{c}\text { Gross growth } \\
\text { efficiency } \\
(P / C)\end{array}$ & $\begin{array}{c}\text { Net growth } \\
\text { efficiency } \\
(P / A)\end{array}$ \\
\hline $10-30$ & 66 & 21 & 32 \\
$15-25$ & 54 & 18 & 34 \\
$15-30$ & 54 & 27 & 51 \\
$15-35$ & 45 & 21 & 48 \\
$24-25$ & 62 & 13 & 20 \\
$24-30$ & 77 & 39 & 51 \\
Analysis included zoeal Stages I-III only; $100 \%$ mortal- \\
ity occurred prior to Stage IV
\end{tabular}

mental regimes tested in this study, the assimilation and growth efficiencies were found to vary. Assimilation efficiencies ranged from 45 to $77 \%$ while net growth efficiencies ranged from 20 to $51 \%$.

Within the crustaceans, assimilation efficiency is thought to be in excess of $60 \%$ (Conover, 1966), and this has generally proven to be the case for larval stages maintained under optimal culture conditions. A cumulative efficiency of $63 \%$ has been reported for larvae of both the stone crab Menippe mercenaria (Mootz and Epifanio, 1974) and the mud crab Rhithropanopeus harrisii (Levine and Sulkin, 1979). Moreover, assimilation efficiency in the American lobster Homarus americanus under optimal culture conditions was $81 \%$ (Logan and Epifanio, 1978). In the present study, assimilation efficiencies for $C$. irroratus larvae were variable and the higher values were not necessarily associated with larvae maintained in optimal conditions. Larvae cultured at $10^{\circ} \mathrm{C}-30 \% \mathrm{~S}$, an environmental regime that does not appear to be optimal - in terms of larval survival (Johns, 1981a), pat- terns of physiological rate functions (Johns, 1981b), or gross and net growth efficiencies (Table 8 ) - exhibited a higher assimilation efficiency than larvae cultured in near optimal regimes.

Net growth efficiencies for Cancer irroratus larvae also varied with temperature and salinity condition, however in this case the higher efficiencies were associated with larvae maintained under optimal conditions. Efficiencies of between 32 and $34 \%$ were found in those larvae which exhibited a $20 \%$ survival rate (Johns, 1981a) while those larval groups which had survival rates in excess of $50 \%$ had net growth efficiencies of 48 to $51 \%$.

These data suggest that a rock crab larva's ability to acquire needed energy resources and effectively partition this energy between maintenance and growth processes is dependent on environmental factors. Modification of the energy budget for Cancer irroratus is evident when changes in either temperature or salinity occur. Reductions in daily ingestion rates and total amount of food consumed during larval development were found. In addition, the energy requirements for maintenance greatly increased in some conditions thus reducing the potential for growth.

The increase in energy costs for maintenance can be taken as the energetic cost of incomplete compensation to environmental change. Physiological compensation would have been evident if net growth efficiencies for larvae maintained under various regimes would have remained the same. Similarity in net growth efficiencies indicates a constancy in the relative ratio in which available energy resources are partitioned between growth and maintenance requirements. Compensation, for example, is evident in rock crab larvae maintained between $15^{\circ}$ and $24^{\circ} \mathrm{C}$ at $30 \% \mathrm{~S}$. Larvae exposed to these 2 conditions exhibited little change in net growth efficiency (Table 8). Although larvae maintained at $24^{\circ} \mathrm{C}-30 \% \mathrm{~S}$ consumed less energy during development than did larvae 
maintained at $15^{\circ}-30 \% \mathrm{~S}$, compensation for this reduction was brought about by an increased assimilation efficiency. Therefore the energy available for growth remained the same

Conversely, incomplete compensation for temperature is evident for larvae cultured at $10^{\circ} \mathrm{C}-30 \% \mathrm{~S}$ relative to those maintained at $15^{\circ} \mathrm{C}-30 \% \mathrm{~S}$. As was the situation for larvae cultured at $24^{\circ} \mathrm{C}$, larvae maintained at $10^{\circ} \mathrm{C}$ consumed less food than did those at $15^{\circ} \mathrm{C}$ during development. Unlike the larvae in $24^{\circ} \mathrm{C}$, however, the increase in assimilation efficiency was not sufficient to compensate completely for this reduced feeding rate. In addition, increased maintenance costs reduced the amount of energy available for growth.

Similar shifts in the partitioning of energy can also be seen with changes in salinity. Rock crab larvae cultured at $15^{\circ} \mathrm{C}-25 \%$ S exhibited a net growth efficiency of $24 \%$ during larval development while those maintained at $15{ }^{\circ} \mathrm{C}-30 \% \mathrm{~S}$ had an efficiency of $51 \%$. Although there was only a slight reduction in the amount of energy consumed by the larvae in $25 \% \mathrm{~S}$ ( $6 \%$ reduction) total growth was $37 \%$ less than that for larvae maintained in $30 \% \mathrm{~S}$. Increases in the cost for maintenance as well as energy lost as excreta account for this reduction in growth.

The above data demonstrate that Cancer irroratus larvae which are unable to compensate physiologically for environmental change exhibit reduced growth potential. How this affects larval survival during development is not known. Experimental evidence for other crustaceans which might help to further an understanding is lacking. However, Bayne and his coworkers (Bayne, 1973; Bayne, 1975; Bayne et al., 1975; Bayne et al., 1978; Gabbot and Bayne, 1973; Widdows, 1978) have studied the effects of environmental factors on growth, reproduction and survival of the mussel Mytilus edulis. Their research indicates that organisms which are unable to compensate physiologically for environmental change (viz. under stress) and exhibit a reduced potential for growth, are generally more vulnerable to further environmental change. Additional environmental change (increase in stress) results in further physiological imbalance which may lead to death (Brett, 1958).

Cancer irroratus larvae can be collected in the Narragansett Bay from May when water temperatures range from $9^{\circ} \mathrm{C}$ (Hillman, 1964) to October, when water temperatures can reach $23^{\circ} \mathrm{C}$ (Frolander, 1955; Bigford, 1979); salinity fluctuates only slightly over this period, staying within 29.5 to $32 \% \mathrm{~S}$ (Bigford, 1979). Peak spawning occurs between mid-June and mid-August when water temperatures vary between $14^{\circ}$ and $18^{\circ} \mathrm{C}$ (Jones, 1973). Johns (1981a) has calculated that during dispersal from Narragansett Bay $C$. irroratus larvae would encounter similar conditions to those reported above. The combined energy budgets of this study represent, albeit incomplete, an ecological energy budget for Cancer irroratus larvae. These data, in addition to information on the survival (Johns, 1981a) and performance of individual physiological functions under various conditions (Johns, 1981b), furnish an estimate of the ecological fitness of rock crab larvae. High survival rates, performance of physiological functions and the apparent complete physiological compensation for the temperature range of $15^{\circ}$ to $24^{\circ} \mathrm{C}$ suggested that the peak production of larvae by adult populations within the Narragansett Bay region coincides with conditions when maximum tissue growth is possible. In contrast, rock crab larvae spawned earlier in the season or transported into lower salinity waters would be subjected to physiological stresses which could result in reducing their growth potential and, ultimately, their survival.

Acknowledgements. This study was part of the dissertation submitted to the University of South Carolina, USA, in partial fulfillment of the requirements of the degree of Doctor of Philosophy. I wish to acknowledge the helpful comments and criticisms of colleagues and thesis committee members: Drs. W. B. Vernberg, D. C. Miller, S. Stancyk, P. DeCoursey, R. Gardner and J. Scott. Portions of this research were supported by a United States Environmental Protection Agency Fellowship.

\section{LITERATURE CITED}

Bayne, B. L. (1973). Physiological changes in Mytilus edulis L., induced by temperature and nutritive stress. J. mar. biol. Ass. U.K. 53: 39-58

Bayne, B. L. (1975). Aspects of physiological conditions in Mytilus edulis (L.), with special reference to the effects of oxygen tension and salinity. In: Barnes, H. (ed.) Proceedings of 9th European Marine Biology Symposium. Aberdeen University Press, Aberdeen, pp. 213-238

Bayne, B. L., Abbot, P. A., Widdows, J. (1975). Some effects of stress in the adult on the eggs and larvae of Mytilus edulis L. J. mar, biol. Ass. U.K. 55: 675-689

Bayne, B. L., Holland, D. L., Moore, M. N., Lowe, D. M., Widdows, J. (1978). Further studies on the effects of stress in the adult on the eggs of Mytilus edulis. J. mar. biol. Ass. U.K. 58: 825-841

Bayne, B. L., Widdows, J. (1978). The physiological ecology of two populations of Mytilus edulis L. Oecologia (Berl.) 37 : $137-162$

Bigford, T. E. (1979). Synopsis of biological data on the rock crab, Cancer irroratus Say. NOAA Tech. Rep., NMFS Circular No. 426: 1-26

Brett, J. R. (1958). Implications and assessments of environmental stress. In: Larkin, P. A. (ed.) The investigation of fish power problems; H. R. MacMillan lectures in fisheries. University British Columbia Press, Vancouver, pp. $69-83$

Brody, S. (1945). Bioenergetics and growth, Reinhold Publishing Corp., New York

Conover, R. J. (1966). Assimilation of organic matter by zooplankton. Limnol. Oceanogr. 11(3): 338-345 
Dagg, M. J. (1974). Loss of prey body contents during feeding by an aquatic predator. Ecology 55: 903-906

Frolander, H. T. (1955). The biology of the zooplankton of the Narragansett Bay area. Ph.D. thesis, Brown University, Providence, Rhode Island

Gabbott, P. A., Bayne, B. L. (1973). Biochemical effects of temperature and nutritive stress on Mytilus edulis L. J. mar. biol. Ass. U.K. 53: 269-286

Grunbaum, B. W., Schulz, A. R., Kirk, P. L. (1955). Determination of oxygen uptake by tissue growth in an all-glass differential microrespirometer. Mikrochim. Acta 1955: $1069-1075$

Hillman, N. S. (1964). Studies on the distribution and abundance of decapod larvae in Narragansett Bay, Rhode Island, with consideration of morphology and mortality, M.S. thesis, University of Rhode Island, Kingston, Rhode Island

Hochachka, P. W., Somero, G. N. (1973). Strategies of biochemical adaptation, W. B. Saunders, Philadelphia

Johns, D. M. (1980). Larval development and bioenergetics of Cancer irroratus (Say) larvae under optimal and sub-optimal conditions of temperature salinity. Ph.D. thesis, University of South Carolina, Columbia

Johns, D. M. (1981a). Physiological studies on Cancer irroratus larvae. I. Effects of temperature and salinity on survival, development rate and size. Mar. Ecol. Prog. Ser. 5: 75-83

Johns, D. M. (1981b). Physiological studies on Cancer irroratus larvae. II. Effects of temperature and salinity on physiological performance. Mar. Ecol. Prog. Ser. 6: 309-315

Johns, D. M., Pechenik, J. A. (1980). The influence of the water-accommodated fraction of No. 2 fuel oil on the energetics of Cancer irroratus larvae. Mar. Biol. 55: $247-254$
Johns, D. M., Peters, M. E., Beck, A. D. (1980). International study on Artemia. VI. Nutritional value of geographic and temporal strains of Artemia: effects on survival and growth of two species of brachyuran larvae. In: Persoone, G., Sorgeloos, P., Roels, O., Jaspers, E. (eds.) The brine shrimp Artemia, Vol. 3, Ecology, culture, use in aquaculture. Universa Press, Wetteren, Belgium, pp. 291-304

Jones, C. (1973). The ecology and metabolic adaptations of Cancer irroratus Say. M.S. thesis, University of Rhode Island, Kingston

Levine, D. M., Sulkin, S. D. (1979). Partitioning and utilization of energy during the larval development of the xanthid crab, Rhithropanopeus harrisii (Gould). J, exp. mar. Biol. Ecol. 40: 247-257

Logan, D. T., Epifanio, C. E. (1978). A laboratory energy balance for the larvae and juveniles of the American lobster Homarus americanus. Mar. Biol. 47: 381-389

Maciolek, J. A. (1962). Limnological organic analysis by quantitative dichromate oxidation. Fisheries Res. Rep. No. 60: $1-61$

Mootz, C. A., Epifanio, C. E. (1974). An energy budget for Menippe mercenaria larvae fed Artemia nauplii. Biol. Bull. mar. biol. Lab., Woods Hole 146: 44-55

Sastry, A. N. (1976). Effects of constant and cyclic temperature regimes on the pelagic larval development of a brachyuran crab. In: Esch, G. W., McFarlane, R. W. (eds.) Thermal ecology II ERDA symposium series, 40 pp. $81-87$

Snedecor, G. W., Cochran, W. G. (1967). Statistical methods, lowa State University Press, Ames, Iowa

Solorzano, L. (1969). Determination of ammonia in natural waters by the phenolhypochlorite method. Limnol. Oceanogr. 14: 799-801

Widdows, J. (1978). Physiological indices of stress in Mytilus edulis. J. mar. biol. Ass. U.K. 58: 125-142

This paper was presented by Professor F. J. Vernberg; it was accepted for printing on January 5, 1982 